\title{
Histopathological and ultrastructural changes in the gill and liver of fresh water fish Channa punctatus exposed to sodium arsenite
}

\author{
Titikksha Das ${ }^{1 *}$ and Mamata Goswami \\ ${ }^{1}$ Department of Zoology, Gauhati University, Guwahati, 781014, Assam \\ ${ }^{2}$ Department of Zoology, Cotton College, Guwahati, 781001, Assam
}

\section{ABSTRACT}

Arsenic, is one of the most important and concerned global environmental toxicants. Correlations have been found between chronic arsenic poisoning and many severe health effects including cancers, hypertension and ischemic heart disease etc. However, the proper understanding of the role of arsenic in the cause of these diseases is still limited. In this work, we studied the toxicity effect of sodium arsenite in the gill and liver tissues of fresh water fish Channa punctatus and for the first time observed the histopathological as well as surface ultrastructural changes on it. The liver and gill tissues of Channa punctatus were exposed to sub-lethal (12 ppm: parts per million) concentration of sodium arsenite (NaAsO2) for 96 hours. The histopathological effects of sodium arsenite on the liver and gill tissues were studied by light microscopy. The surface ultrastructural changes on the same tissues were investigated by scanning electron microscopy (SEM). The results were compared with the normal structure of liver and the gill tissue of a control group of Channa punctatus. Gill tissues exposed to arsenic showed hyperplasia, desquamation, and necrosis of epithelium, epithelial lifting, oedema, lamellar fusion, collapsed secondary lamellae, curling of secondary lamellae and aneurism in the secondary lamellae. Hepatic lesions in the form of cloudy swelling of hepatocytes, congestion, vacoular degeneration, karyolysis, dilation of sinusoids and nuclear hypertrophy were observed in the liver tissue of the exposed group. Thus it has been shown that sodium arsenite can produce significant damage in the ultrastructure of liver and gill tissues. Also the histological and ultrastructural changes on the liver and the gill tissue indicate that arsenic is biologically reactive and gives rise to acute poisoning.

KEY WORDS: CHANNA PUNCTATUS, GILL, HISTOPATHOLOGY, LIVER, SODIUM ARSENITE

\section{ARTICLE INFORMATION:}

*Corresponding Author: titikkshadas.89@gmail.com Received $12^{\text {th }}$ July, 2018

Accepted after revision $27^{\text {th }}$ Sep, 2018

BBRC Print ISSN: 0974-6455

Online ISSN: 2321-4007 CODEN: USA BBRCBA

$\because$ \%.\% Thomson Reuters ISI ESC / Clarivate Analytics USA and

: Crossref Indexed Journal

NAAS Journal Score 2018: 4.31 SJIF 2017: 4.196

- A Society of Science and Nature Publication, Bhopal India 2018. All rights reserved.

Online Contents Available at: http//www.bbrc.in/

DOI: $10.21786 / \mathrm{bbrc} / 11.3 / 12$ 


\section{INTRODUCTION}

Contamination of water by arsenic compounds and its toxicological effect on aquatic organism is a major worldwide problem. Geogenic processes and anthropogenic disturbances are the two main causes of dispersal of arsenic in aquatic environment (Bears et. al., 2006; Gonazalez et. al., 2006). Several countries including Argentina, Bangladesh, Chile, China, India, Japan, Mexico, Mongolia, Nepal, Poland, Taiwan, Vietnam, and some part of United States have been reported with high concentration of arsenic in groundwater (Anowar et. al., 2002; Mitra et. al., 2002; Smith et. al., 2001; Chowdhury et. al., 2000). A correlation has been found between chronic arsenic poisoning and many health effects including cancers, melanosis, hyperkeratosis, restrictive lung disease, peripheral vascular disease, gangrene in leg, skin, lung, bladder, liver, diabetes mellitus, hypertension and ischemic heart disease (Anawar et. al., 2002). It is evident that arsenic exposure has multiple effects at the molecular level for instance liver chromosomal DNA fragmentation, expression of certain proteins, differential expression of genes involved in cell cycle regulation, signal transduction, stress response, apoptosis, cytokine production, growth-factor and hormone-receptor production (Hossain et. al., 2003; Tabellini et. al., 2005; Ahmed et. al., 2008; Sangeeta et. al., 2012 Paruruckumani et al., 2015).

Both in laboratory and field studies histopathological investigations have been long recognised as reliable biomarkers of stress in fish and in the evaluation of the health of fish exposed to contaminants. The gills, liver and kidney are the common primary target organs for many chemicals primarily because of their vital role within the body (Chowdhury et. al., 2000; Hossain et. al., 2000, Paruruckumani et al., 2015).

In this work, we studied the toxicity effect of sodium arsenite in the gill and liver tissues of fresh water fish Channa punctatus and for the first time observed the histopathological as well as surface ultrastructural changes on it. We also estimated a critical value of concentration of sodium arsenite above which fishes are likely to be killed. A commonly useful measure of toxicity LC50 is used for this purpose. The goal of this study was, firstly, to observe any histological changes, arsenic could bring to the vital organs of living animal and secondly, to substantiate the role of arsenic as a toxic environmental agent which can cause many severe health effects.

\section{MATERIALS AND METHODS}

For the present study healthy and disease free fishes Channa punctatus (weight 22-50 gm) were collected from local markets in Guwahati. After disinfection with a dip of $2 \%$ potassium permanganate $\left(\mathrm{KMnO}_{4}\right)$ solution the fishes were acclimatised in aquaria for two weeks before initiation of experiment. The water provided in the aquaria was from the tap water in the laboratory and was changed on the following day. The fishes were fed everyday with fish food available in the market. Proper aeration was done during these periods. Sodium Arsenite $\left(\mathrm{NaAsO}_{2}\right)$, molecular weight-129.91 Merck, India (Ltd.) was procured for performing the experiment. A stock solution was prepared with water from which the test concentration was prepared by dilution. The control group of fishes were kept in similar conditions without adding sodium arsenite. Fishes were exposed to 5 different concentration of Sodium Arsenite of 5, 15, 25, 35 and 45 ppm. The toxicity bioassay was performed in semi-static system in triplicate with 10 specimens exposed for each concentration in each set in accordance with the standard methods of acute toxicity bioassay procedures (APHA, 2005).

Fishes were transferred to each aquarium and exposed to five different concentrations such as 5, 15, 25, 35 and $45 \mathrm{ppm}$ of sodium arsenite. In all cases, control groups of fishes were maintained. Each experimental trial was carried out for a period of 96 hours. The mortality rate of the fish was recorded at logarithmic time intervals that is, after 6, 12, 24, 48, 72 and 96 hours of exposure. The test media was renewed daily during the experimental period. The data obtained in course of the investigation were analysed statistically to see whether there is any influence of different treatment concentrations on the mortality of the fish. Fishes were exposed to sub lethal concentration i.e. $12 \mathrm{ppm}$ of sodium arsenite along with a control group for 96 hours. At the end of the exposure period, fishes were randomly selected for histopathological examinations. Gill, liver, tissues were isolated from normal and experimental fish. Physiological saline solution $(0.75 \% \mathrm{NaCl})$ was used to rinse and clean the tissue. They were fixed in aqueous Bouins solution for 24 hours, processed through graded series of alcohols, cleared in xylene and embedded in paraffin wax. Sections were cut at 4 micron thickness and stained with Hematoxylin and eosin stain. Histopathological lesions were examined and photographed with the help of computer attached Bright Field Microscope (Leica DM 3000).

Gills and liver tissues of both the control and treated groups were rapidly removed and processed routinely for scanning electron microscopic studies. Gills and liver tissues were cut into small pieces of $1 \mathrm{~mm}$ thickness and fixed in $2.5 \%$ glutaraldehyde prepared in cacodylate (sodium phosphate) buffer adjusted to $\mathrm{pH} 7.4$ for 24 hours and afterward washed in phosphate buffer for 15 min. After dehydration in ascending series of acetone, samples were immersed in Tetra Methyl Silane for 10 minutes at 4 degree centrigrate. Then they were brought to room temperature to dry. The specimens were mounted on Aluminium Stubs coated with gold and observed 
through scanning electron microscope in Sophisticated Analytical Instrument Facility (SAIF), North-Eastern Hill University (NEHU), Shillong - 793022.

\section{RESULTS AND DISCUSSION}

The mortality rate of Channa punctatus to different concentration of sodium arsenite can be seen in Figure 1. In the present study, it was observed that $45 \mathrm{ppm}$ sodium arsenite in water induced death of all the exposed fishes within 96 hours. The 96 hours LC50 of sodium arsenite for Channa punctatus was found to be $25 \mathrm{ppm}$. Fishes treated with a concentration of 5, 10 and 12 ppm sur- vived for more than 90 days with zero mortality rates. The sub lethal concentration of sodium arsenite for the exposed group of fish was $12 \mathrm{ppm}$. The control group of fish were in good condition without any morphological changes. But the sodium arsenite treated fish showed rapid movement of fins and operculum. They produced a lot of slime around their body. Their overall activities decreased with time

In the liver tissue of control channa punctatus, there was normal structure and systematic arrangement of hepatocytes. Hepatic cells were roundish, polygonal containing clear spherical nucleus which can be seen in the Figure 2. The normal histological arrangement was

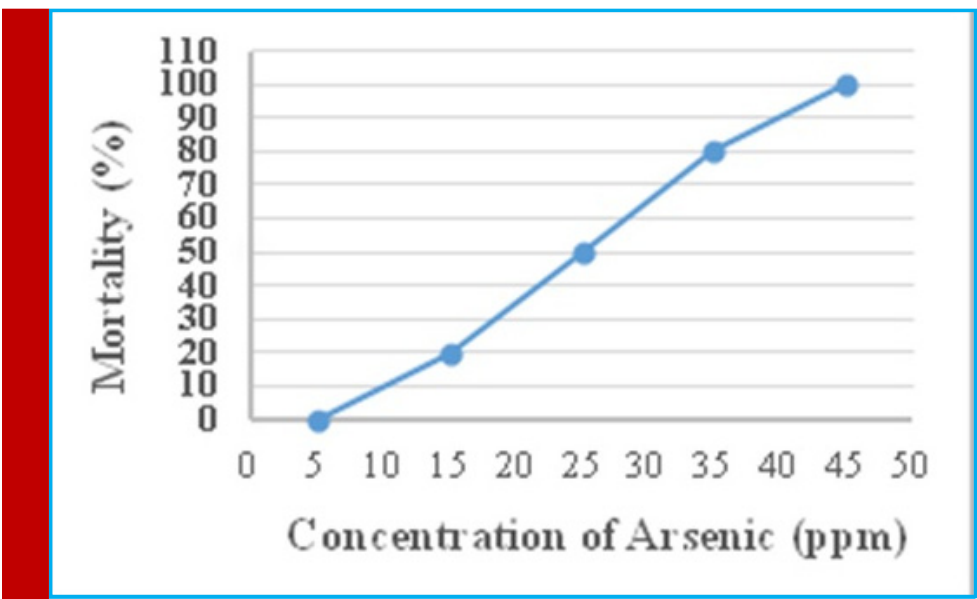

FIGURE 1. Graphical representation of 96 hours LC50 of Sodium arsenite treated Channa Punctatus. It shows mortality rate of Channa Punctatus to different concentration of sodium arsenite, (ppm: parts per million).

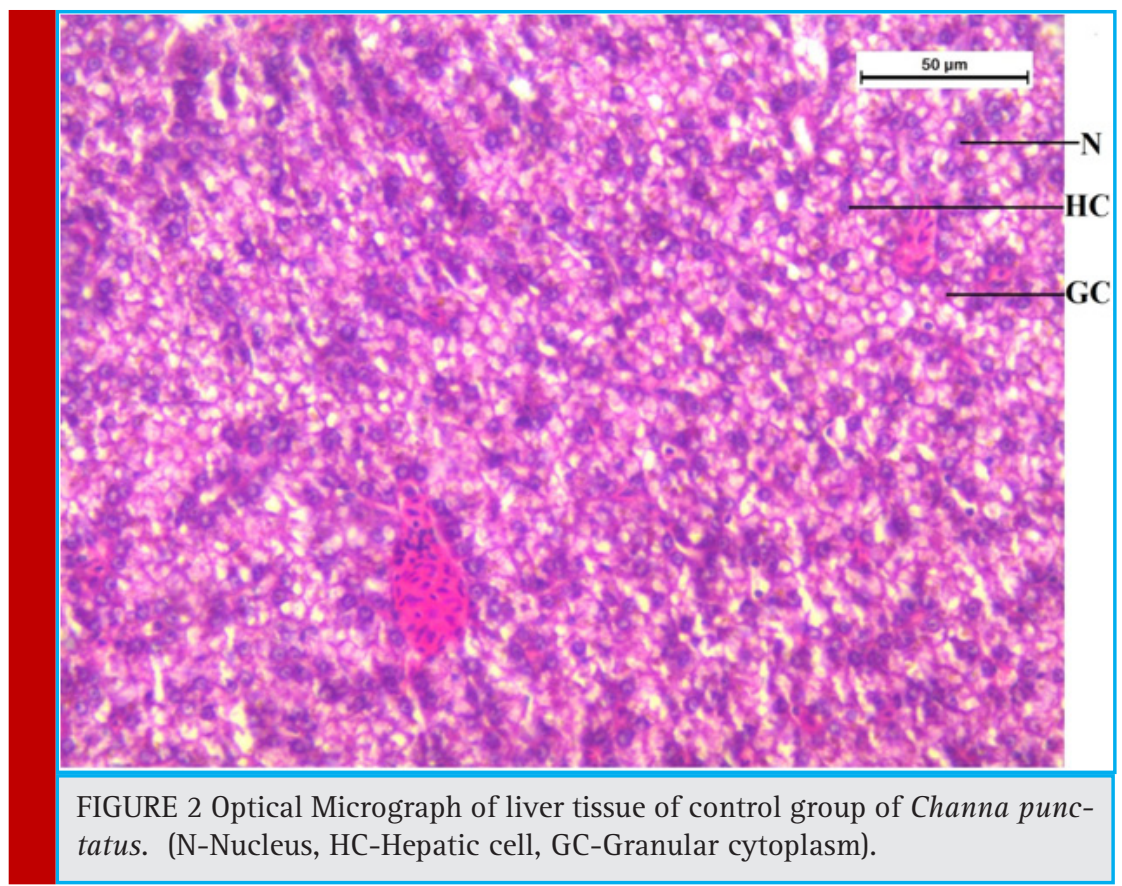




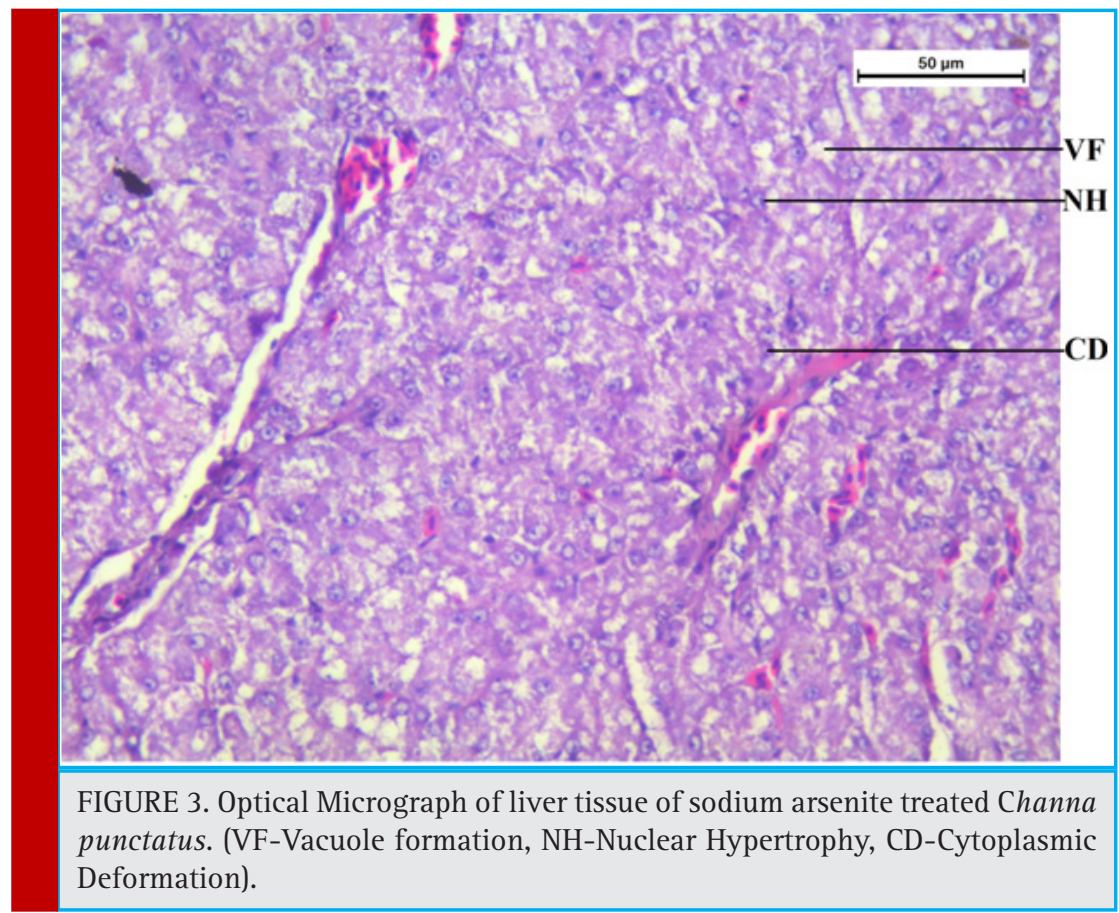

not found in the liver tissue of sodium arsenite treated channa punctatus. A micrograph of liver tissue of sodium arsenite treated channa punctatus is shown in the Figure 3. The micrograph shows a lot of rupture of blood vessels, necrotic tissue with marked loss of hepatocytes and extensive area of vacuolation in the liver tissue. Figure 3 also reveals large lipid droplets and abundant glycogen in most of the area of hepatocytes of liver tissue.
A Scanning Electron Micrograph of liver tissue in control channa punctatus is shown in the Figure 4 which represents normal ultrastructural morphology of hepatocytes. Serous membranes with some connective tissue are seen in the surface of the liver tissue. Hepatic cells are seen with clear spherical nucleus. Liver is the primary organ for detoxification of foreign compounds (Gernhofer et al., 2011) and one of the most affected

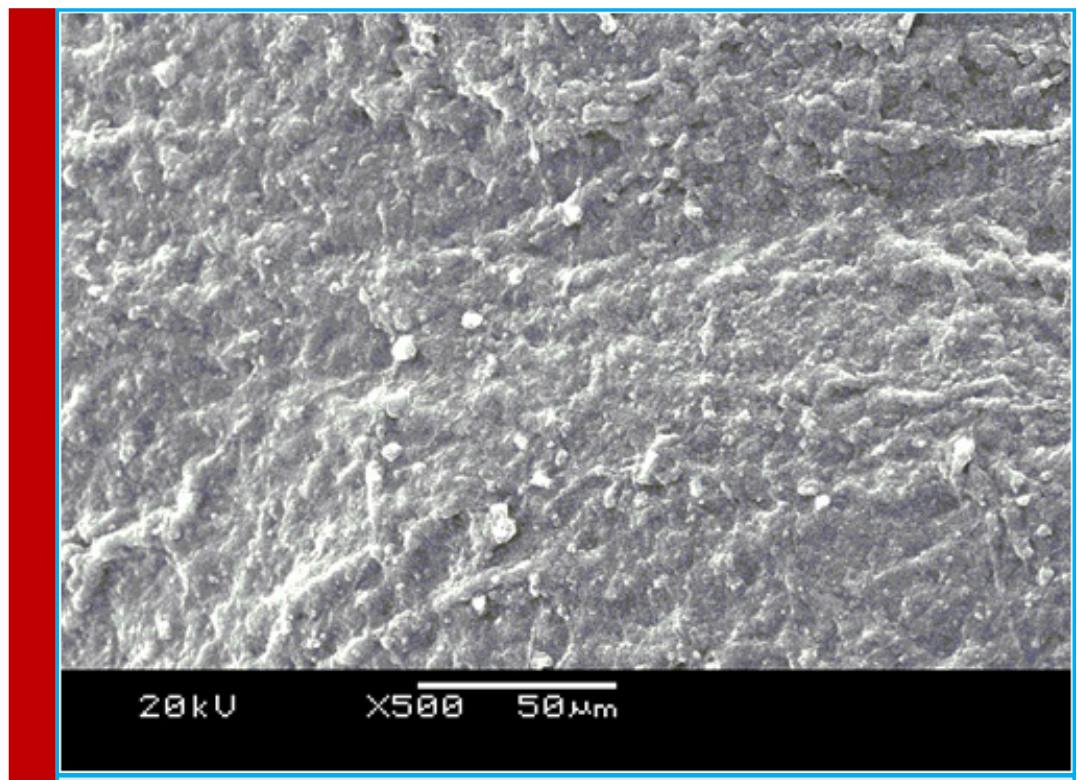

FIGURE 4. Scanning Electron Micrograph of Liver tissue in the controlgroup of Channa punctatus. 


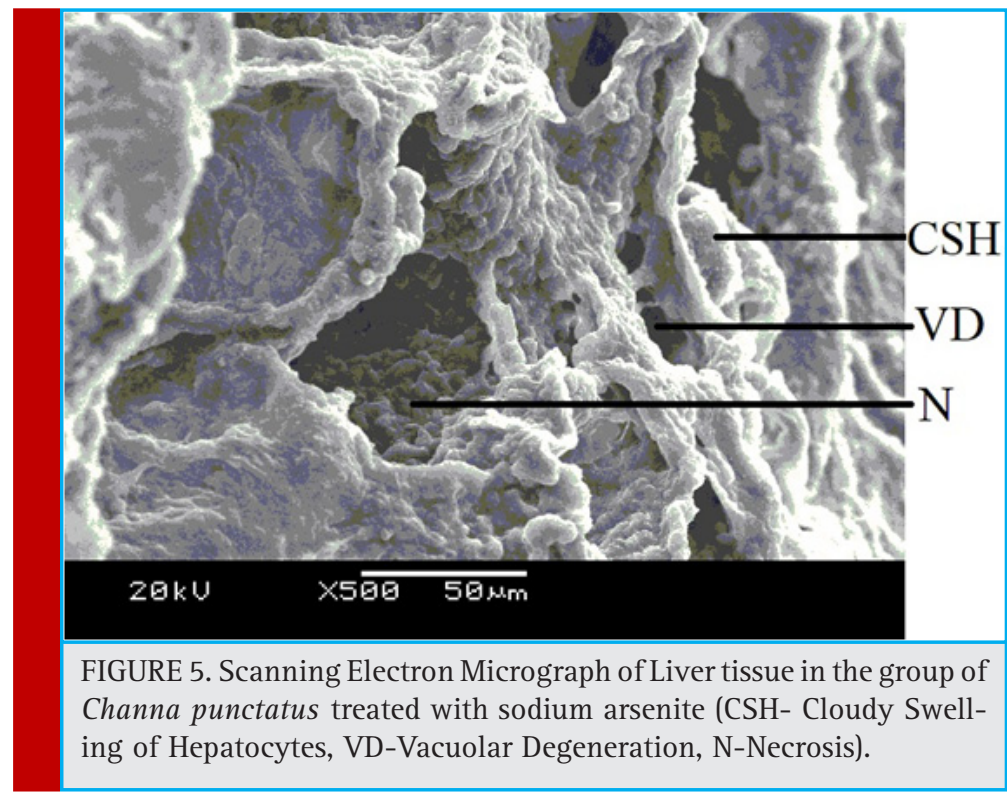

organs by contaminants in water (Camargo, Martinez, 2007). In our study it has been found that sodium arsenite caused several damages in the liver tissue which includes destruction of normal arrangement of the cells, vacuolar degeneration of cytoplasm, necrosis and cloudy swelling of hepatocytes. These changes are represented in the Figure 5. In earlier studies (Ahmed et al., 2008; Sangeeta et al., 2012) on sodium arsenite treated Channa punctatus showed concentration dependent reduced cell viability and chromosomal DNA fragmentation of liver cells. Finding of Ahmed et al., 2008, revealed that lower concentration of sodium arsenite induced apop- totic death of cells while higher concentration induced necrotic cell death.

In Channa punctatus there are four pairs of semicircular gill arches. Each gill arch has a row of microscopic primary gill lamellae on which secondary gill lamellae are arranged bilaterally. In the control group normal structure of gill lamellae were observed (Figure 6). The histology of the treated sub lethal exposure revealed loss of structural integrity of lamellae. It also shows destruction of cartilaginous gill bar, degenerated primary and secondary gill lamellae, lamellar fusion and capillary lumen and that can be clearly seen from Figure 7. Anal-

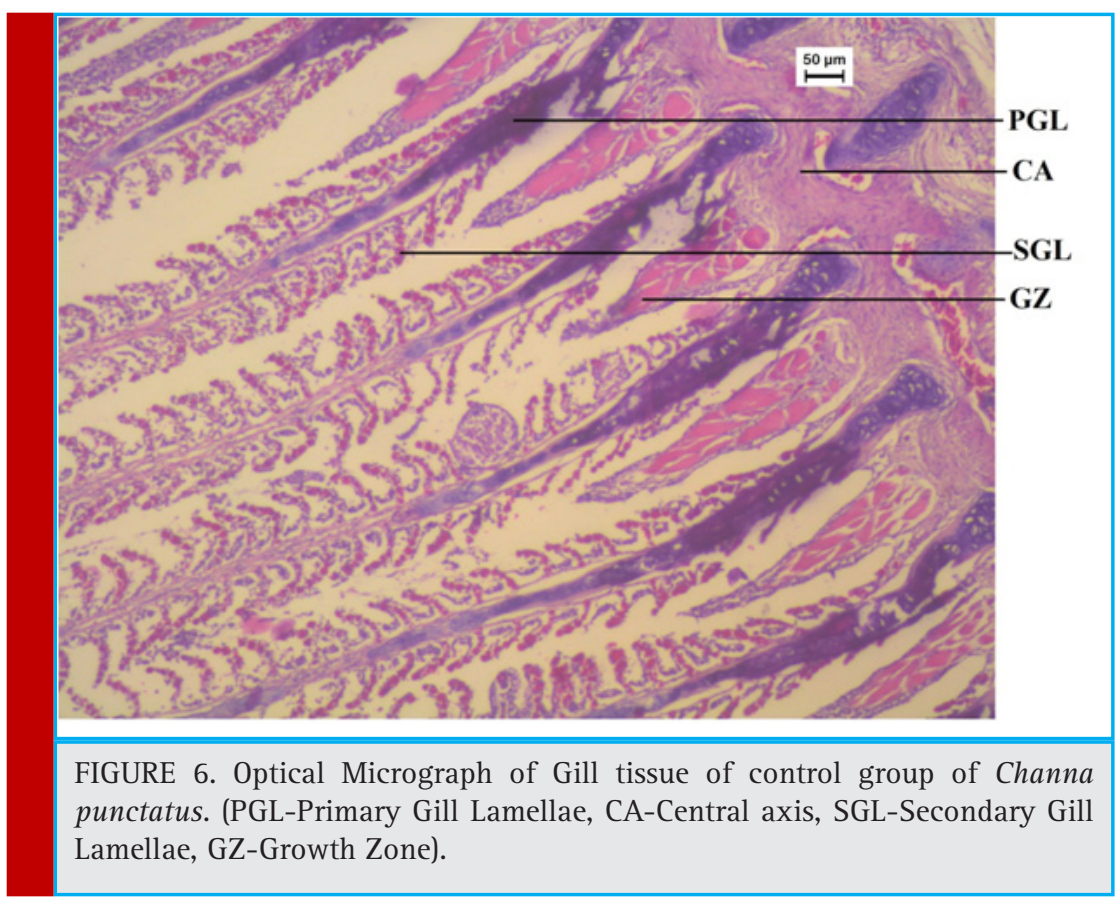




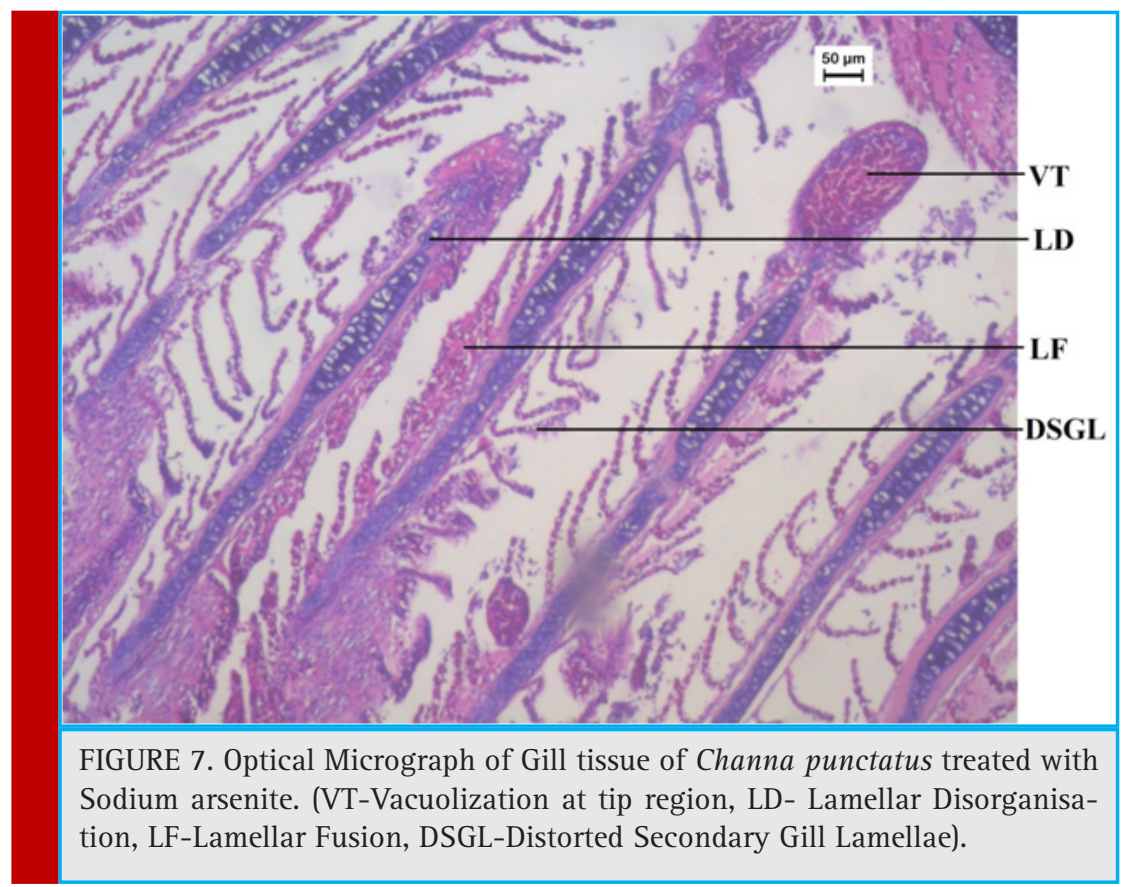

ogous structural changes could be seen from the gill tissue of Channa punctatus exposed to arsenic trioxide (Agnihotri et al., 2010). Their findings revealed degenerative changes in cartilaginous bar and increased mucous secretion between the spaces of primary gill lamella while capillary lumen developed enlarged spaces in gills of Channa punctatus exposed to arsenic trioxide. The secondary gill lamellae of arsenic trioxide treated fish showed destruction of epithelial cells, vacuolization in the tip of the primary gill ray, gill hyperplasia and lamellar fusion (Agnihotri et al., 2010). Pathological lesions in the gill tissue induced by sodium arsenite were similar to cadmium induced gill tissue of Labeo rohita (Muthu- kumaravel et al., 2013). Copper induced gill tissues of Oreochrombis mossambicus showed marked alternations which were studied by Radhika and Krishnamoorthy (Radhika et al., 2010).

Figure 8 shows a normal architecture of gills in the control group of fish. Normal structure of primary gill lamella, secondary gill lamella and micro ridges on the normal gill epithelium were observed. In the gill tissue of sodium arsenite treated fish fusion of secondary lamella, necrosis and deformation of the gill tissue were observed and that can be seen in the Figure 9. The SEM micrograph of gill in sodium arsenite treated Channa Punctatus (Figure 9) also reveals swelling and curling

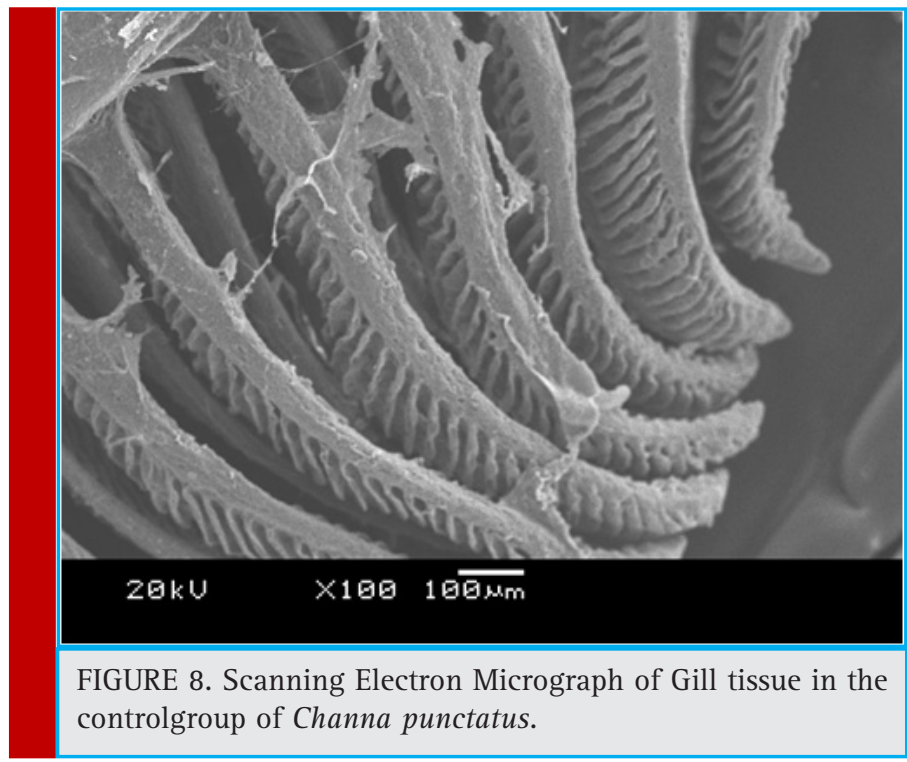




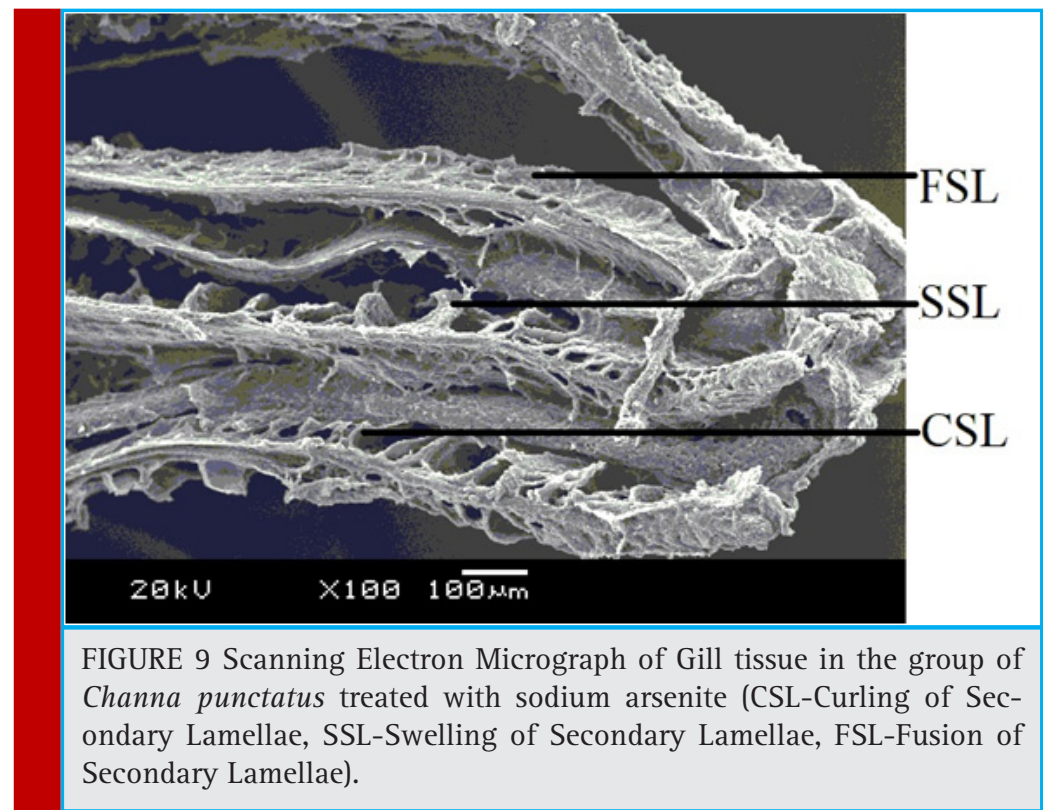

of secondary lamellae, complete fusion of secondary lamellae and surface wrinkling in numerous areas of the gill tissue. These observations are in accordance to those reported in Surface ultrastructural changes in the gill and liver tissue of Asian sea bass Lates calcarifes (Bloch) exposed to copper (Paruruckumani et al., 2015)

\section{CONCLUSION}

This work presents a unique evidence of arsenic toxicity in fishes and how its sub lethal concentration causes ultrastructural damages on gill and liver tissue. We also have seen high sensitivity and behavioural changes in the treated fish. The data obtained from the concentration dependent study of sodium arsenite to Channa punctatus can be used to set a standard for human exposure to arsenic. Further studies on the nature of arsenic induced damages observed on the cellular structure of the concerned tissue could provide some insight into the mechanism of arsenic poisoning on human being.

\section{REFERENCES}

Anwar, H. M., Akai, J., Mostofa, K. M., Saifullah, S., \&t Tareq, S. M. (2002). Arsenic poisoning in ground water health risk and geochemical sources in Bangladesh. Environ In, 36, 962-968.

Ahmed, K., Akhand, A. A., Hasan, M., Aslam, M., \&t Hasan, A. (2008). Toxicity of arsenic (Sodium Arsenite) to fresh water spotted snakehead Channa punctatus (Bloch) on cellular death and DNA content. American-Eurasian J Agric \& Environ Sci, 4, 18-22.

Agnihotri, U. S., Bahadure, R. B., \&t Akarte, S. R. (2010). Gill lamellar changes in fresh water fish Channa punctatus due to influence of arsenic trioxide. Biosci Biotech Res Comm, 3, 61-65.

Bears, H., Richards, J. G., \&t Schulte, P. M. (2006). Arsenic exposure alters hepatic arsenic species composition and stress mediated gene expression in the common Killifish (Fundulus heteroclitus). Aqua Toxico, 77, 257-266.

Chowdhury, U. K., Biswas, B. K., Chowdhury, T. R., Samanta, G., Mandal, B. K., \&t Basu, G. C. (2000). Ground water arsenic contamination in Bangladesh and West Bengal, India. Environ Health Perspect, 108, 393-397.

Camargo, M. M., \&t Martinez, C. (2006). Biological and physiological biomarkers in Prochilodus lineatus submitted to in situ tests in an urban stream in southern Brazil. Environ Toxicol Pharmacol, 21, 61-69.

Gernhofer, M., Pawet, M., Schramm, M., Muller E., \& Triebskorn, R. (2011). Ultrastructural biomarkers as tools to characterize the health status of fish in contaminated streams. Aqua Ecosyst Stress Recov, 8, 241-260.

Gonazalez, H. 0., Roling, J. A., Baldwin W. S., \&t Bain, L. J. (2006). Physiological changes and differential gene expression in mummichog (Fundulus heteroclitus) exposed to arsenic. Aqua Toxico, 77, 43-52.

Hossain, K., Akhand, A. A., Kato, M., Du, J., Takeda, K., Wu, J., Takeuchi, K., Liu, W., Suzuki, H., \&t Nakashima, I. (2000). Arsenic induces apoptosis of murine $\mathrm{T}$ lymphocytes through membrane raft-linked signaling for activation of c-Jun aminoterminal kinase. J Immunol,165, 4290-4297.

Hossain, K., Akhand, A. A., Kawamoto, Y., Du, J., Takeda, K., Wu, J., Youshihara, M., Tsuboi, H., Takeuchi, K., Kato, M., Suzuki, H., \&t Nakashima, I. (2003). Caspase activation is accelerated by the inhibition of arsenic-induced, membrane raftdependant Akt activation. Free Radic Biol Med, 34, 598-606.

Mitra, A. K., Bose, B. K., Kabir, H., Das, B. K., Et Hussain, M. (2002). Arsenic-related health problems among hospital 
patients in southern Bangladesh. J Health Popul Nutr, 20, 198204.

Muthukumaravel, K., Prithiviraj, N., Ramesh, M., Sekar, V., \&t Sheik Mohamed Salahuen, B. (2013). Light and scanning electron microscopic evaluation and effect of Cadmium on the gill of the freshwater fish, Labeo rohita. Int J Pharmace Biol Arch, 4, 999-1006.

Paruruckumani, P. S., Maharajan, A., Ganapiriya, V., Narayanaswamy, Y., \&t Raja Jeyasekar, R. (2015). Surface ultrastructural changes in the gill and liver tissue of Asian sea bass Lates calcarifes (Bloch) exposed to copper. Biol Trace Elem Res, 168, 5000-5007.

Radhika, R., \&t Krishnamoorthy, R. (2010). Effect of copper sulphate on histological changes in the fresh water fish Oreo- chromic Massambicus. J Ecotoxicol Environ Monit, 20, 431435.

Smith, A. H., Lingas, F. O., \&t Rahman, M., (2001). Contamination of drinking-water by arsenic in Bangladesh: A public health emergency. Bull World Health Organ, 78, 1023-1103.

Sangeeta, D., Unni, B., Bhattacharjee, M., Wann, S. B., \& Gangadhar Rao, P. (2012). Toxicological effects of arsenic exposure in a freshwater teleost fish Channa punctatus, African J Biotech, 11, 4447-4454.

Tabellini, G., Tazzari, P. L., Bortul, R., Evanquelisiti, C., Billi, A. M., Grafone, T., Baccarani, M., \&t Martelli, A. M. (2005). Phosphoinositide 3-Kinase/Akt inhibition increases arsenic trioxide-induced apoptosis of acute promyelocytic and T-cell leukaemias. J Haematol, 130, 716-725. 